\title{
Variations
}

Variations

Revue internationale de théorie critique

$21 \mid 2018$

L'industrie de la culture : version originale

\section{Adorno in the Kingdom of Unfreedom - History and Freedom's Lecture The Principle of Nationality}

Athina Karatzogianni

\section{OpenEdition}

Journals

Édition électronique

URL : http://journals.openedition.org/variations/943

DOI : 10.4000/variations.943

ISSN : 1968-3960

Éditeur

Les amis de Variations

Référence électronique

Athina Karatzogianni, «Adorno in the Kingdom of Unfreedom - History and Freedom's Lecture The Principle of Nationality », Variations [En ligne], 21 | 2018, mis en ligne le 05 avril 2018, consulté le 20 avril 2019. URL : http://journals.openedition.org/variations/943 ; DOI : 10.4000/variations.943

Ce document a été généré automatiquement le 20 avril 2019

Les ami•e•s de Variations 


\title{
Adorno in the Kingdom of Unfreedom - History and Freedom's Lecture The Principle of Nationality
}

\author{
Athina Karatzogianni
}

\section{Introduction}

1 By 1964, Adorno could see the first clouds of disagreement with his students on the horizon, who were mobilizing against proposed legislation on the Emergency Laws and the American War in Vietnam: 'Admittedly, from 1967 on this opposition in part adopted forms of protest that Adorno was to condemn emphatically as "pseudo-activity". Not content with merely interpreting the world, the students called for social change, and Adorno's lectures represented something of an attempt to provide theoretical analysis of this situation by refocusing attention on the relations between theory and practice'... 'when the students demanded guidance for political practice. It was for this reason that he wanted to discuss the question of theory and practice again, quite explicitly, in the summer of 1969, at the height of the student movement'... 'but he never gave more than a few lectures because it was repeatedly disrupted and he was forced to cancel it.' (Editor's forward in Adorno, 2006: xviii). His lectures were disrupted in protest of Adorno and his colleagues calling the police to clear 70 students in January 1969 from the institute, who they thought they were going to occupy the premises. It is at that fateful period at the end of that semester that Adorno takes his annual leave and dies on a mountain vacation.

Freyenhagen (2014) examines Adorno's conflict with the student movement concerning the practical implications of his critical theory, with one of his PhD students accusing him of detachment and complicity with the ruling powers, socialist students distributing leaflets in December 1968 accusing him of being critical in theory and conformist in practice, while Marcuse and others joined the chorus of accusing him of a politically objectionable 'quietism'. Feyerhagen reconstructs and partially defends Adorno's views on theory and praxis in the Germany of the 1960s in 11 theses, and they are worth 
summarizing him here for the purpose of our discussion: 1 . The transformation of the world failed and the realization of philosophy missed period from Russian Revolution to later stages of the First World war; 2. Praxis is postponed as in revolutionary activity because the proletariat and those who could transform the world have been materially integrated and tyrannical outcome of the Soviet Union, China and Asia, whilst no appropriate forms of revolutionary, but non- repressive, collective agency have yet developed; 3. the modern social world engenders an antinomical structure of our option space, such that whatever we do, we cannot but act and live wrongly; 4. Theory has priority in the current conditions, i.e. 'main factors towards renewed barbarism is the integration, even poisoning of conscious- ness, against which theorizing can offer some immunization strategies.' (ibid. 873); 5. Adorno believes theory should maintain a certain independence especially vis-a'-vis direct political action and tactic; 6 . Democracy has shallow roots; 7. Political activity in the West should be critical, but broadly defensive, here Adorno's 'defence of western liberal democracies rests on instrumental and historical grounds - on avoiding the worst in a given situation' (p.879). 9. Political violence should be restricted to resistance in fascist contexts; 10. Assigning primacy to political activity, actionism [Aktionismus] is the true resignation in the face of our social world 'self-styled acts of resistance and provocation are, in fact, mere compensatory measures of keeping busy - indeed, he once likens them to captured animals that frantically pace up and down in their cages' (ibid. 882). 11. Participation in political activity requires justification to each individual. In sum, Feyerhagen provocatively concludes 'that Adorno's view comes down to saying that people have tried to change the world, in various ways; the point in the 1960s was to interpret it.' (ibid. 885).

This is the overall context from which I intend to now launch a close reading and interpretation of Lecture 12 'The Principle of Nationality'. Because it is here, I believe, that Adorno, in his treatment of Hegel, nurtures a blind spot, which will cost him his relationship with the student movement, in the last few years before his death.

\section{Eingedenken in the Amphitheatre: Lecture 12}

4 The first lecture of his philosophy of history class starts 10 November 1964. Students attend Tuesdays and Thursdays, all the way to the $28^{\text {th }}$ Lecture he delivers 25 February 1965. The $12^{\text {th }}$ Lecture (17 December 1964) stands before Adorno and his Christmas holiday after which he is to resume with his students again on 5 January 1965. By the time he hits The Principle of Nationality on the $17^{\text {th }}$ of December, his students have sat through: the concept of freedom in Kant and Hegel, the meaning of history refuted by Auschwitz, the concept of universal history and rationality as form of conflict, the universal denounced as metaphysics and negativity as a universal, the French Revolution, public company for the exploitation of nature, the course of the world and individual conscience, negative universal history, temporal core and non-identity, history as a gigantic exchange relationship, the nation and the spirit of people in Hegel, and the cult of the nation. After Christmas, Adorno will deliver on Marx the ironical Social Darwinist, critique of historicity, history as secularized metaphysics, theory of interpretation, Kant's idea of humanity, progress as mythical and anti-mythical, bourgeois coldness and privileged happiness, decadence and utopia, the concept of exchange, freedom as the epitome of resistance to the spell, the possibility of freedom in unfreedom, what is free will, bourgeois ambivalence, freedom in the service of oppression, evil as unfreedom, 
narcissistic interest in freedom, obsessional neurosis; the ego-alien ego, Freud's theory of repression, consciousness versus causality, and solidarity and heteronomy in matters of conscience, amongst others.

In Lecture 12, Adorno starts by summarizing the nation as a specifically bourgeois form of organization: 'Nations, or many nations, are transforming themselves into something like huge companies, vast economic entities, and remain like that even if free trade tendencies may temporarily mitigate their strict organization with, outwardly at least.' (Adorno, 2006: 105). He follows with 'if we regard nations as a form of organization appropriate to the rational constitution of bourgeois society viewed as an economic system, thus implies that they replace natural forms of association, which are then brought together in the modern nation' (ibid.). Here, he patiently explains to his students that the nation developed as a struggle against feudalism, which was a world historical force, but because of its basis in the family it was an essentially natural form of organization. Nationalism retreats from these natural bonds, but suppresses them, taking over some of their features, forcing it to act as if it were itself a natural form of society.

6 Adorno calls nationalism a primal pseudos, because although it is a dynamic, economic and historical association, it misconstrues itself ideologically as natural. He goes on to show how racism colludes with nationalism '...the idea of the nation has possessed what today we would call a romantic element that culminates in the delusions of racism (ibid. 7) and explains this mechanism as follows: 'Mind has become estranged from nature and even from itself, so that in this situation racism represents the mind's compensation for what has been done to it, for the nature that has been suppressed in it. This nature then reappears in perverse form, namely as fiction, and in that guise, it necessarily assumes the destructive qualities we have seen in nationalism throughout its entire history...' (ibid.). Adorno identifies nationality as the result of a historical turn: 'But then, around the tie the political victory of the bourgeoisie over absolutism, something happened. At the same time as the curbing of absolutism blunted the last vestige of feudalism still surviving into the bourgeois era, nationality turned into that truly pernicious, destructive phenomenon that we have come to experience.' (ibid. 8).

7 So far so good, but then he produces a critique of Hegel. This is where lecture 12 becomes a bit of a mishap, a thriller, and a revelator about Adorno's own philosophy of history.

\section{"Hegel is himself not above the suspicion" or how the mode of production outdates the principle of nationality}

Adorno's critique of Hegel begins with Hegel's belief that race is a natural given and his failure to inquire into the mechanism 'that enables a national consciousness to persist even when it has been rendered obsolete by history' (ibid. 8). There is this tendency as early as Hegel, he argues, 'to stabilize things that have been rendered obsolete by the passage of time, and if possible, to restore them' (ibid. 9), and Hegel did so by converting them to historical constants. And while Hegel might have had some justification 'the nation has now been reduced to a mere façade by the uniformity of the organization of life on an international plane.' (ibid.). He supports this by bringing in some form of contemporary example: airports. This is worth citing in full: 
9 If you have the opportunity to fly long distances and to see - just to mention the most obvious fact - how all over the world airports resemble one another, by which I mean the entire business of loudspeakers, hostesses and everything that goes with them, you will indeed find it hard to resist the impression that other differences between individual town exist largely only to motivate passengers to travel from one to another, from Karachi to Naples or elsewhere. (ibid.)

10 In lieu of this, Adorno argues that it is a convergence of countless spheres of life and forms of production, the convergence of fundamental processes of life subjugates to industrial production and compares with this, the differences between nations are 'merely rudimentary vestiges' (ibid. p. 110). Hegel's national spirits which have the status of principle and are conceived as eternal are now outdated. Hegel's national spirits, the nations, are anachronisms '-unless we go so far (and Hegel is himself not above the suspicion that he has gone so far on occasion) as to sever all inks between the spirit or the world spirit and actual human reason and individual reason, and to hypostasize them.' (p. 112). Additionally, the fetishization of the nation occurs in especially highly developed for where nation-building is a failure. Contemporary examples to the $21^{\text {st }}$ century are now up for grab.

11 What is Adorno's proposal for a way out to his students during this lecture?

12 So today, the task is not simply to conserve the concrete essence of human relations in the transitory form of different nations - which incidentally has long been unmasked as fraudulent - but to bring about this concrete state of human community on a higher plane. And by a superior state, I do not mean a mechanical union of superpowers joined together in even more gigantic blocs.... What I have in mind is something that would change the form of society itself and put an end to the abstract organization that acts so repressively towards its members. This is by no means as utopian as it sounds on first hearing, if only because modern technology already opens up the possibility of decentralization that actually makes it unnecessary to bring societies together in gigantic hierarchical entities. This means that the historical form of progressive rationalization has ceased to be the most rational way of doing things and it survives only in the interests of the existing relations of production. In the meantime, however, it would be possible to organize societies far more rationally in much smaller units that could collaborate peaceably with one another and from which all those aggressive and destructive tendencies would have been banished. But, oddly enough, it is precisely the technical advances towards decentralization that have been neglected. (ibid. 11).

\section{The contemporary relevance of the History and Freedom Lectures}

In juxtaposition to Adorno's airport cosmopolitanism as a global reality, another shift has occurred, whereby the industrial production that outdated Hegel's national spirits, in turn has itself been outdated by what Benjamin Bratton calls The Stack (2015: 156 his italics):

Looking at airports as a model for intermodal information exchange, we see that the global mobility of people and things is possible in part because of the protocological standardization of an interfacial network of airports and cities, arranged by increments of firs-person travel time, hub-and-spoke econometrics, and its flattening affectless provisionality of boarding lounge culture..."Singaporization" of the global city, positioned at a critical interface connecting urban nodes within an expanded global sphere, is the model for the city as rendered as information hardware and software... Perhaps as counterintuitively as interfaces become ubiquitous, interface decentralization becomes the 
engine of Cloud centralization, and as these interfaces become channels of increasing end User management, swarm intelligence, and spontaneous utility, Cloud centralization becomes as well the engine of interface decentralization. The logic of the City layer of the Stack power is thus both decentralized top-down and centralized bottom-up, as well as directed side-to-side interaction monetized as raw social currency of cognition and circulation.

With that hopeful technology and decentralization opportunity culminating in the latest capitalist tragedy, coopted and recuperated in the manner Bratton explicated right above, I would argue that the contemporary relevance of Adorno's History and Freedom (1964-65) Lectures instead flow within the following streams:

to our alienation in a fully administered society, where we can explore our precarious position in the Anthropocene (Nagelhout, 2016): 'By Adorno's account, for art to tap the cognitive potential outlined in Aesthetic Theory, one must extend the To do so, art must accept chaos and reject "sleekly polished images of life" $(1997,94)$, partake in the "impoverishment of the subject" (1997, 30), and remain steadfast in trying to reconcile the irreconcilable' (2016:122).

18 Subjectivity and Negative Dialectics. Adorno's forced collapsing of subjective interiority into a negative space that opens up aesthetic emancipatory potential: 'And his first and foremost measure in doing so is to break down an assumed interior life of inner 'decisionism' of the subject. By decisionism I mean an irrational adherence to one's falsely assumed capacity to make ethical, moral, religious choices without any mediation of socio-political life or other materially relevant, concrete contexts that impinge upon one's subjectivity' (Morgan, 2016: 168). Following on from this, Adorno's concept of 'nonidentity', the mismatch between concepts and objects 'The convulsions and internal contradictions our conceptual systems exhibit in attempting to fully subsume objects testify to the former; the ability of the claims of empirical science to be falsified by the behavior of objects testifies to the latter...As we will see, Adorno ties this epistemic and modal resistance in with his materialism' (Hulatt, 2016: 482). Here Hulatt critiques Adorno's ontology and epistemology as bifurcated, behaving differently when applied to social as opposed to non-social ontology which promises future investigations into Adorno's scholarship, ibid. 483).

19 Critique of neoliberalism as second nature. Prusik (2017) develops an analysis of neoliberal economics through Adorno's concept of natural-history (Naturgeschichte), in order to articulate the formation of what terms as neoliberal "second nature." He identifies identifying the natural logic of the market's immanent self-determination, so he can demonstrates the way in which social relations and institutions of coercion are legitimated through their appearance as natural necessity.' (p. 165). Drawing from Adorno, Prusik argues that the science of economics implicitly dissolves the historical content of society, mobilizing 'a mythic concept of nature as justification for its reduction of life to an economic logic' (p.167).

20 Digital technologies, emergence of racism, fascism, nationalism. Les Back is analyzing relationship between digital technologies, racism and the emergence of new patterns of racist culture within trans-local and international coordinates. Surprisingly, in his empirical analyses he finds two of Adorno's essay included on the racist sites he examines and the surrealism jumping out of this account: "The writer struggles to situate Adorno's writing on the culture industry within a white nationalism worldview. For 'Siegfried' Adorno's argument is puzzling since he is critical of an industry in which some of the 
proponents happen to be Jews: 'One might well ask why Adorno would attack his own tribesmen (i.e. fellow Jews) in public?' (Back, 2002: 637). This is the kind of surrealism Adorno himself would have appreciated no end.

Happiness and inner health under capitalism. Here it is Busk (2016) that takes an Adornian take and drives it home while commenting on capitalism as a happiness machine: 'This doctrine operates on the principle that "inner health" is identifiable with happiness in one's situation, and that successful treatment amounts to successful adjustment to the demands of work and painless integration into society. The objective character of this situation is left to one side, as if unhappiness and maladjustment were not or could not be expressions of a degrading social and material reality but only "disorders." Happiness, in this case, becomes compulsory, and a critical discontentment with the present social reality (rather than to some of its accidental or individual aspects) is forbidden.' (p. 525)

The concept Addendum as resisting unfreedom. As Jaffe (2017) 'addendum' names the experience by which socially constrained agents are jolted into resistance against their suffering. The impulse to action is simultaneously intra-mental and somatic, and thus forms the locus of a jointly conscious and bodily impetus to confronting the ideological and material forces that produce contemporary unfreedom.' (p.838). The term plays a key role in the History and Freedom Lectures before it appears in Negative Dialectics a year later. I think it is this where Adorno could force an alliance with his students to find strategies out of the Kingdom of Unfreedom, 'but oddly enough', as he like to say, it was another missed opportunity.

\section{BIBLIOGRAPHIE}

Adorno, T.W. (2006) History and Freedom: Lectures 1964-1965, ed. R. Tiedemann, trans. R. Livingston, Cambridge: Polity Press.

Bachmann, V. and Sidaway, J.D. (2016) ‘Brexit Geopolitics’, Geoforum 77, pp. 47-50.

Black, L. (2002) ‘Aryans Reading Adorno: Cyber-culture and Twentieth Century Racism', Ethnic and Racial Studies, 25: 4, pp. 628-651.

Bradley, D. (2009) ‘Oh That Magic Feeling! Multicultural Human Subjectivity, and Fascism's

Footprints', Philosophy of Music Education Review, 17: 1, pp. 56-89.

Bratton, B. (2015) The Stack: On Software and Sovereignty, Cambridge: MA, MIT Press.

Busk, L.A. (2016) 'It's a Good Life? Adorno and the Happiness Machine', Constellations, 23:4, pp. 523-535.

Freyenhagen, F. (2014) ‘Adorno's Politics: Theory and Praxis in Germany’s 1960s', Philosophy and Social Criticism, 40:9, pp. 867-893.

Hulatt, O. (2016) ‘Modal and Epistemic Immodesty: An Incoherence in Adorno's Social Philosophy', Constellations, 23:4, pp. 482-493.

Jaffe, A. (2017) ‘Adorno's “Addendum”, Philosophy and Social Criticism, 43:8, pp. 855-876. 
Morgan, M. (2016) 'The Affect of Dissident Language and Aesthetic Emancipation at the Margins: A Possible Dialogue between Theodor W. Adorno and Julia Kristeva', Journal of French and Francophone Philosophy - Revue de la philosophie française et de langue française, XXIV: 1, pp. 167-191. Nagelhout, M. (2016) 'Nature and the Industry that Scorched It': Adorno and the Anthropocene Aesthetics’, Symploke, 24:1-2, pp. 121-135.

Prusik, C.A. (2017) 'Economics as Natural-History: Adorno and the Critique of Neoliberalism', Architecture and Culture, 5:2, 165-174.

INDEX

Mots-clés : Theodor W. Adorno, Nationalität, nationality, Eingedenken, Reich der Freiheit

\section{AUTEUR}

\section{ATHINA KARATZOGIANNI}

Associate Professor, University of Leicester 